\title{
Hubungan Antara Pusat dan Daerah Dalam Negara Kesatuan Republik Indonesia Berdasarkan Undang-Undang Nomor 23 Tahun 2014
}

\author{
Septi Nur Wijayanti
}

DATA NASKAH

Masuk: 7 September 2015

Diterima: 19 Oktober 2016

Terbit: 8 Desember 2016

KORESPONDEN PENULIS:

Fakultas Hukum Universitas Muhammadiyah Yogyakarta Jalan Lingkar Selatan Tamantiro Kasihan Bantul Yogyakarta

Email: septiwijayanti@ymail.com

\section{ABSTRACT}

Act Number 23 of 2014 about Local Government arranged on $2^{\text {th }}$ October 2014 altered the relationship face between Central Government and Local Government. Regional autonomy that has been run solely understood as the shifting obligation from central government to local government for society. While the importance substance from regional autonomy is delegation of authority from the central to the local economically and politically, righteous development and economic progress. So that the concept of regional autonomy within the framework of Unitary State of Indonesia is more emphasized in Act Number 23 of 2014. Another fundamental change not mentioned in Act Number 22 of 2014 is the enactment of Mandatory Reginal Affairs and Concurrent Affairs Pattern Relationship between Central Government, Province, and Dictrict/City that in a direct way included in Annex Act Number 23 of 2014. In Article 9 of Act Number 23 of 2014 classified that government affair consists ofabsolute government affair, concurrent government affair, and public government affair. $t$ can be concluded that the provision of Act Number 23 of 2014 on Regional Government still leads to decentralization, seen from the existence of matter distribution although classified into 3 government affairs. If referring to a theoretical model of the relationship between the Central Government and Local Government according to Clarke and Stewart, decelntralization as this included into the Agency Model. This is a kind of model in which government does not have sufficient power which simply means that its presence is seen more as central government agent in charge to run its government to run its central government's policies. Keywords: Decentralization, Regional Autonomy, Unitary State, Central and Regional Relationship, Governmental Affairs

\section{ABSTRAK}

Undang-undang Nomor 23 Tahun 2014 tentang Pemerintahan Daerah yang diundangkan pada tanggal 2 Oktober 2014 merubah wajah 
hubungan Pemerintah Pusat dan Pemerintah Daerah. Otonomi daerah yang dijalankan selama ini semata-mata hanya dipahami sebagai perpindahan kewajiban pemerintah pusat kepada pemerintah daerah untuk masyarakat. Padahal substansi penting dari otonomi daerah adalah pelimpahan kewenangan dari pusat ke daerah secara politik dan ekonomi agar pembangunan dan pertumbuhan ekonomi berlangsung secara adil dan merata di daerah. Sehingga konsep otonomi daerah dalam kerangka Negara Kesatuan Republik Indonesia ini yang ditekankan lebih tajam dalam Undang-Undang Nomor 23 tahun 2014. Perubahan yang mendasar lain yang tidak ada dalam Undang-Undang Nomor 32 Tahun 2004 ialah ditetapkannya Urusan Wajib Daerah, dan pola hubungan Urusan Konkuren antara Pemerintah Pusat, Provinsi dan Kabupaten/Kota yang langsung dimasukkan dalam Lampiran Undang-Undang Nomor 23 Tahun 2014. Dalam Pasal 9 Undang-Undang Nomor 23 Tahun 2014 diklasifikasi urusan Pemerintahan terdiri atas urusan pemerintahan absolut, urusan pemerintahan konkuren, dan urusan pemerintahan umum. Dapat disimpulkan bahwa ketentuan UU Nomor 23 Tahun 2014 tentang Pemerintahan Daerah masih mengarah pada desentralisasi, dilihat dari adanya pembagian urusan meskipun diklasifikasikan secara rinci ke dalam 3 urusan pemerintahan. Jika merujuk pada teori model hubungan antara Pemerintah Pusat dan Pemerintah Daerah secara teoritis menurut Clarke dan Steward, desentralisasi seperti ini termasuk The Agency Model. Model dimana pemerintah daerah tidak mempunyai kekuasaan yang cukup berarti sehingga keberadaannya terlihat lebih sebagai agen pemerintah pusat yang bertugas untuk menjalankan kebijaksanaan pemerintah pusatnya.

Kata kunci: Desentralisasi, Otonomi Daerah, Negara Kesatuan, Hubungan Pusat Dan Daerah, Urusan Pemerintahan

\section{PENDAHULUAN}

Reformasi di bidang politik dan administrasi pemerintahan kembali digelar dengan disahkannya UndangUndang Nomor 23 Tahun 2014 tentang Pemerintahan Daerah untuk mengganti Undang-Undang 32 Tahun 2004 yang tidak sesuai lagi dengan perkembangan keadaan, ketatanegaraan, dan tuntutan penyelenggaraan pemerintahan daerah. Muatan Undang-Undang Pemerintahan Daerah tersebut membawa banyak perubahan dalam penyelenggaraan pemerintahan. Salah satunya adalah pembagian urusan pemerintahan antara Pemerintah pusat dan Pemerintah Daerah.

Latar belakang perlunya ditetapkan Undang-Undang Nomor 23 Tahun 2014, antara lain: (a) Menjamin efektifitas penyelenggaraan pemerintahan daerah dalam rangka meningkatkan kesejahteraan rakyat; (b) Menata manajemen pemerintahan daerah yang lebih responsive, akuntabel, transparan, dan efesien; (c) Menata keseimbangan tanggung jawab antar tingkatan/susunan pemerintahan dalam menyelenggarakan urusan pemerintahan; (d) Menata pembentukan daerah agar lebih selektif sesuai dengan kondisi dan kemampuan daerah; dan (e) Menata hubungan pusat dan daerah dalam sistem Negara Kesatuan Republik Indonesia.

Undang-undang Nomor 23 Tahun 2014 tentang Pemerintahan Daerah yang diundangkan pada tanggal 2 Oktober 2014 merubah wajah hubungan Pemerintah Pusat dan Pemerintah Daerah. Secara hukum maka Undangundang Nomor 32 tahun 2004 dinyatakan sudah tidak berlaku lagi, dan dalam masa 2 (dua) tahun kedepan seluruh perubahan dan peraturan pelaksanaan yang diatur dalam Undang-Undang Nomor 23 tahun 2014 harus ditetapkan. Otonomi daerah yang dijalankan selama ini semata-mata hanya dipahami sebagai perpindahan kewajiban pemerintah pusat kepada pemerintah daerah untuk masyarakat. Padahal substansi penting dari otonomi daerah adalah pelimpahan kewenangan dari pusat ke daerah secara politik dan ekonomi agar pembangunan dan pertumbuhan ekonomi berlangsung secara adil dan merata di daerah. Sehingga konsep otonomi daerah dalam kerangka Negara Kesatuan Republik Indonesia ini yang ditekankan lebih tajam dalam Undang-Undang Nomor 23 tahun 2014. Perubahan yang mendasar lain yang tidak ada dalam Undang-Undang Nomor 32 tahun 2004 ialah ditetapkannya Urusan Wajib Daerah, dan pola hubungan Urusan Konkuren antara Pemerintah Pusat, Provinsi dan Kabupaten/ Kota yang langsung dimasukkan dalam Lampiran Undang-Undang Nomor 23 tahun 2014, tidak dibuat menjadi Peraturan Pemerintah seperti pada 


\section{MEDIA
HUKUM}

Undang-Undang Nomor 32 Tahun 2004 (Peraturan Pemerintah Nomor 38 Tahun 2007) yang mengatur hubungan Pemerintah Pusat, Provinsi dan Daerah) (http:// birokrasi.kompasiana.com/2014/12/24/enam-perda-urusanwajib-pemerintah-daerah-698638.html, diakses pada tanggal 6 Mei 2015).

Klasifikasi urusan pemerintahan terdiri dari 3 urusan yakni urusan pemerintahan absolut, urusan pemerintahan konkuren, dan urusan pemerintahan umum. Urusan pemerintahan absolut adalah Urusan Pemerintahan yang sepenuhnya menjadi kewenangan Pemerintah Pusat. Urusan pemerintahan konkuren adalah Urusan Pemerintahan yang dibagi antara Pemerintah Pusat dan Daerah provinsi dan Daerah kabupaten/kota. Urusan pemerintahan umum adalah Urusan Pemerintahan yang menjadi kewenangan Presiden sebagai kepala pemerintahan.

Adanya pembagian 3 urusan ini menimbulkan hubungan yang baru antara pemerintah pusat dan pemerintah daerah, apalagi dalam pelaksanannya ada skala prioritas urusan pemerintahan yang harus dilaksanakan. Pembagian urusan kewenangan tersebut dikontrol oleh pemerintah pusat dengan menerapkan norma, standar, prosedur, dan kriteria (NPSK) dalam rangka penyelenggaraan Urusan Pemerintahan; dan pemerintah pusat melaksanakan pembinaan dan pengawasan terhadap penyelenggaraan Urusan Pemerintahan yang menjadi kewenangan Daerah.

Oleh karena itu sangat perlu dilakukan kajian terhadap pembagian urusan pemerintahan pusat dan daerah dalam Undang-undang Nomor 23 Tahun 2014 tersebut yang akan berimplikasi dengan hubungan pusat dan daerah dalam kerangka negara kesatuan republik Indonesia.

\section{PEMBAHASAN}

1. Asas Otonomi Dan Desentralisasi Dalam Negara Kesatuan

Salah satu aspek konstitusional penyelenggaraan negara dan pemerintahan sejak Indonesia merdeka adalah persoalan yang berkaitan dengan penyelenggaraan otonomi sebagai subsistem negara kesatuan (Manan, 2001:21). Berdasarkan Pasal 1 ayat (1) Undang-Undang Dasar 1945 Negara Indonesia ialah negara kesatuan yang berbentuk Republik. Prinsip pada negara kesatuan ialah bahwa yang memegang tampuk kekuasaan tertinggi atas segenap urusan negara ialah Pemerintah Pusat tanpa adanya delegasi atau pelimpahan kekuasaan kepada Pemerintah Daerah (Local Government) (Lubis, 1983:8). Dalam negara kesatuan terdapat asas bahwa segenap urusan-urusan negara tidak dibagi antara pemerintah pusat (central government) dengan Pemerintah lokal (Local Government) sedemikian rupa, sehingga urusan-urusan negara dalam negara kesatuan tetap merupakan suatu kebulatan (eenheid) dan bahwa pemegang kekuasaan tertinggi di negara itu ialah Pemerintah Pusat (Huda, 2014:241).

Di dalam negara kesatuan, pemerintah pusat menjalankan kedaulatan tertinggi negara. Agar tidak sewenang-wenang, aktivitas pemerintah pusat diawasi dan dibatasi oleh undang-undang. Konsekuensi logis dari posisinya sebagai penyelenggara kedaulatan negara, maka unit-unit pemerintahan yang dibentuk dan berada di bawah pemerintah pusat, harus tunduk kepada pemerintah pusat. Tanpa disertai ketundukan dan kepatuhan secara organisasional berdasarkan peraturan perundang-undangan yang berlaku, akan menjadi tumpang tindih dan tabrakan dalam pelaksanaan kewenangan (prinsip unity command) (Wasistiono, 2004:9).

Di dalam negara kesatuan tanggung jawab pelaksanaan tugas-tugas pemerintahan pada dasarnya tetap berada di tangan Pemerintah Pusat. Akan tetapi, karena sistem pemerintahan Indonesia salah satunya menganut asas negara kesatuan yang didesentralisasikan, maka ada tugas-tugas tertentu yang diurus sendiri, sehingga menimbulkan hubungan timbal balik yang melahirkan adanya hubungan kewenangan, keuangan, pengawasan, dan antar satuan organisasi pemerintahan (Huda, 2014:241).

Substansi pembagian daerah dalam Negara Kesatuan Republik Indonesia diatur dalam pasal 18 ayat (1) UndangUndang Dasar 1945 yang berbunyi "Negara Kesatuan Republik Indonesia dibagi atas kabupaten dan kota, yang tiap-tiap provinsi, kabupaten dan kota itu mempunyai pemerintahan daerah, yang diatur dengan undang-undang". Perubahan ini dimaksudkan untuk lebih memperjelas pembagian daerah dalam negara Kesatuan Republik Indonesia yang meliputi daerah provinsi dan dalam daerah 
Provinsi terdapat Kabupaten dan Kota. Hal ini juga termaktub di dalam pasal 2 ayat (1) Undang-Undang Nomor 23 Tahun 2014.

Istilah "dibagi atas" (bukan "terdiri atas") dalam ketentuan Pasal 18 ayat (1) bukanlah istilah yang digunakan secara kebetulan. Istilah itu langsung menjelaskan bahwa negara kita adalah negara kesatuan di mana kedaulatan negara berada di tangan pusat. Hal ini konsistensi dengan kesepakatan untuk tetap mempertahankan bentuk negara kesatuan. Berbeda dengan istilah "terdiri atas" yang lebih menunjukkan substansi federalisme karena istilah itu menunjukkan letak kedaulatan berada di tangan negaranegara bagian (MPR RI, 2003:102-103).

Otonomi daerah diadakan bukan sekedar menjamin efisiensi penyelenggaraan pemerintahan. Bukan sekedar pula menampung kenyataan yang luas, penduduk banyak, dan berpulau-pulau. Lebih dari itu, otonomi daerah merupakan dasar memperluas pelaksanaan demokrasi dan instrumen mewujudkan kesejahteraan umum. Tidak kalah penting, otonomi daerah merupakan cara memelihara negara kesatuan. Daerah-daerah otonomi yang bebas dan mandiri mengatur dan mengurus rumah tangga pemerintahan sendiri, merasa diberi tempat yang layak dalam kehidupan berbangsa dan bernegara, sehingga tidak ada alasan untuk keluar dari RI (Manan, 2001:3).

Lebih lanjut disampaikan Bagir Manan (Manan, 2001:26) otonomilah sebagai ujung tombak usaha mewujudkan kesejahteraan. Mengingat fungsi kesejahteraan akan menghadapkan pemerintahan pada kenyataan konkret yang berbeda-beda antara daerah satu dengan daerah lain serta berkembang mengikuti dinamika kebutuhan masyarakat setempat, maka dalam otonomi harus tersedia ruang gerak yang cukup untuk melakukan kebebasan menjalankan pemerintahan. Untuk memungkinkan penyelenggaraan kebebasan tersebut dan sekaligus mencerminkan otonomi sebagai satuan demokratis, maka otonomi senantiasa memerlukan kemandirian atau keleluasaan. Bahkan tidak berlebihan apabila dikatakan hakekat otonomi adalah kemandirian, walaupun bukan suatu bentuk kebebasan sebuah satuan yang merdeka. Untuk mewujudkan kemandirian atau keleluasaan, otonomi berkait erat dengan pola hubungan antara pusat dan daerah yang meliputi berbagai segi yaitu hubungan kewenangan, hubungan pengawasan, hubungan keuangan dan lain sebagainya.

Otonomi daerah merupakan wujud kehidupan demokrasi dalam konteks penyelenggaraan negara kesatuan (eenheidstaat). Otonomi daerah merupakan wadah kehidupan demokrasi. Rakyat melalui wakil mereka (Dewan Perwakilan Rakyat Daerah), turut serta dalam penyelenggara pemerintahan, berdasarkan otonomi daerah yang dibangun dalam sistem pemerintahan desentralisasi. Rakyat mengatur rumah tangga mereka sendiri dalam rangka penyelenggaraan otonomi daerah (Huda, 2014:411).

Suatu negara kesatuan baru merupakan wujud pemerintahan demokrasi tatkala otonomi daerah dijalankan secara efektif guna pemberdayaan kemaslahatan rakyat, mencakupi kewenangan zelfwetgeving (peraturan daerahperaturan daerah) yang mengakomodir kepentingan rakyat banyak dan penyelenggaraan pemerintahan (zefbestuur) yang diemban secara demokratis. Porsi otonomi daerah tidak cukup dalam wujud otonomi daerah yang luas dan bertanggungjawab, tetapi harus diwujudkan dalam format otonomi daerah yang seluas-luasnya (Marzuki, 2006:161).

Dengan demikian otonomi bukan sekedar mekanisme pemerintahan untuk mewujudkan administrasi negara yang efektif dan efisien. Otonomi adalah salah satu garda depan penjaga negara kesatuan. Sebagai penjaga negara kesatuan, otonomi memikul beban dan pertanggungjawaban pelaksanaan tata pemerintahan yang demokratis berdasarkan atas hukum untuk mewujudkan pemerataan kemakmuran, kesejahteraan, keadilan baik di bidang ekonomi, politik, maupun sosial dengan cara menghormati dan menjunjung perbedaan-perbedaan antar daerah baik atas dasar sosial, budaya, ekonomi, geografi dan lain sebagainya. Pengakuan atas berbagai perbedaan tersebut sangat penting untuk menunjukkan bahwa kehadiran daerah tetap penting di tengah tengah tuntutan kesatuan (Manan, 2001 :vii).

Kalangan ilmuwan pemerintahan dan politik pada umumnya mengidentifikasi sejumlah alasan mengapa desentralisasi perlu dilaksanakan pada sebuah negara, yaitu antara lain (1) dalam rangka peningkatan efisiensi dan efetifitas penyelenggaraan pemerintahan, (2) sebagai wahana pendidikan politik masyarakat di daerah, (3) dalam rangka memelihara keutuhan negara kesatuan atau integrasi 


\section{MEDIA
HUKUM}

nasional, (4) untuk mewujudkan demokrasi dalam penyelenggaraan pemerintahan yang dimulai dari daerah, (5) guna memberikan peluang bagi masyarakat untuk membentuk karir dalam bidang politik dan pemerintahan, (6) sebagai wahana yang diperlukan untuk memberikan peluang bagi masyarakat untuk berpartisipasi dalam proses perencanaan dan pelaksanaan pemerintahan, (7) sebagai sarana yang diperlukan untuk mempercepat pembangunan di daerah, dan yang terakhir adalah (8) guna mewujudkan pemerintahan yang bersih dan berwibawa (Syaukani, dkk, 2009:vii).

Pada hakikatnya, desentralisasi itu sendiri dapat dibedakan dari karakterikstisnya, yaitu; (Darumurti dan Rauta, 2003:47)

1. Desentralisasi teritorial (territorial decentralization), yaitu penyerahan urusan pemerintahan atau pelimpahan wewenang untuk menyelenggarakan suatu urusan pemerintahan dari pemerintah yang lebih tinggi kepada unit organisasi pemerintah yang lebih rendah berdasarkan aspek kewilayahan.

2. Desentralisasi fungsional (functional decentralization), yaitu penyerahan urusan-urusan pemerintahan atau pelimpahan wewenang untuk menyelenggarakan suatu urusan pemerintahan dari pemerintah yang lebih tinggi kepada unit-unit pemerintah yang lebih rendah berdasarkan aspek tujuannya (seperti Subak di Bali).

3. Desentralisasi politik (political decentralization), yaitu pelimpahan wewenang yang menimbulkan hak untuk mengurus diri kepentingan rumah tangga sendiri bagi badan-badan politik di daerah-daerah yang dipilih oleh rakyat. Ini terkait juga dengan desentralisasi teritorial

4. Desentralisasi budaya (cultural decentralization), yaitu pemberian hak kepada golongan-golongan tertentu untuk menyelenggarakan kegiatan kebudayaannya sendiri. Misalnya, kegiatan pendidikan oleh kedutaan besar negara asing, otonomi nagari dalam menyelenggarakan kegiatan kebudayaannya sendiri, dan sebagainya. Dalam hal ini sebenarnya tidak termasuk urusan pemerintahan daerah.

5. Desentralisasi ekonomi (economic decentralization), yaitu pelimpahan kewenangan dalam penyelenggaraan kegiatan ekonomi

6. Desentralisasi administratif (administratif decentraliza- tion), yaitu pelimpahan sebagian kewenangan kepada alat-alat atau unit pemerintahan sendiri di daerah. Pengertiannya identik dengan dekonsentrasi.

Keenam karakteristik desentralisasi tersebut dapat dikaitkan dengan tujuan dan mafaat yang dapat diperoleh dengan ditetapkannya kebijakan desentralisasi dan dekonsentrasi yang pada pokoknya merupakan kebijakan yang diperlukan untuk mengatasi kecenderungan terjadinya penumpukan kekuasaan di satu pusat kekuasaan. Di samping itu, dengan kebijakan desentralisasi dan dekonsentrasi juga diharapkan dapat terwujud fungsi-fungsi kekuasaan negara yang efektif dan efisien, serta terjaminnya manfaat-manfaat lain yang tidak dapat diharapkan dari sistem pemerintahan yang terlalu terkonsentrasi dan bersifat sentralistik (Wijayanti dan Satriawan, 2009:161).

Oleh karena itu ada beberapa tujuan dan manfaat yang biasa dinisbatkan dengan kebijakan desentralisasi yaitu: (Darumurti dan Rauta, 2003:30)

1. Dari segi hakikatnya, desentralsiasi dapat mencegah terjadinya penumpukan (concetration of power) dan pemusatan kekuasaan (centralised power) yang dapat menimbulkan tirani.

2. Dari sudut politik, desentralisasi merupakan wahana untuk pendemokratisasian kegiatan pemerintahan.

3. Dari segi teknis organisatoris, desentralisasi dapat menciptakan pemerintahan yang lebih efektif dan efisien

4. Dari segi sosial, desentralisasi dapat membuka peluang partisipasi dari bawah yang lebih aktif dan berkembangnya kaderisasi kepemimpinan yang bertanggung jawab karena proses pengambilan keputusan tersebar di pusat-pusat kekuasaan di seluruh daerah

5. Dari sudut budaya, desentralisasi diselenggarakan agar perhatian dapat sepenuhnya ditumpahkan kepada kekhususan-kekhususan yang terdapat di daerah, sehingga keanekaragaman budaya dapat terpelihara dan sekaligus didayagunakan sebagai modal yang mendorong kemajuan pembangunan dalam bidang-bidang lainnya.

6. Dari sudut kepentingan pembangunan ekonomi, karena pemerintah daerah dianggap lebih banyak tahu, dan secara langsung berhubungan dengan kepentingan di daerah, maka dengan kebijakan desentralisasi, 
pembangunan ekonomi dapat terlaksana dengan lebih tepat dan dengan biaya yang lebih murah

Hal ini diperkuat oleh oleh Shabbir Cheema and Rondinelli (Syaukani, dkk, 2009: 32-34) menyampaikan paling tidak ada empat belas (14) alasan yang merupakan rasionalitas dari desentralisasi, yaitu:

1. Desentralisasi dapat merupakan cara yang ditempuh untuk mengatasi keterbatasan karena perencanaan yang bersifat sentralistik, dengan mendelegasikan sejumlah kewenangan, terutama dalam perencanaan pembangunan, kepada pejabat di daerah yang bekerja di lapangan dan tahu betul masalah yang dihadapi masyarakat. Dengan desentralisasi maka perencanaan dapat dilakukan sesuai dengan kepentingan masyarakat di daerah yang bersifat heterogen.

2. Desentralisasi dapat memotong jalur birokrasi yang rumit serta prosedur yang sangat terstruktur dari pemerintah pusat.

3. Dengan desentralisasi fungsi dan penugasan kepada pejabat di daerah, maka tingkat pemahaman serta sensitivitas terhadap kebutuhan masyarakat daerah akan meningkat. Kontak hubungan yang akan meningkat antara pejabat dengan masyarakat setempat akan memungkinkan kedua belah pihak untuk memiliki informasi yang lebih baik, sehingga dengan demikian akan mengakibatkan perumusan kebijasanaan yang lebih realistik dari pemerintah.

4. Desentralisasi akan mengakibatkan terjadinya "penetrasi" yang lebih baik dari pemerintah pusat bagi daerah-daerah terpencil atau sangat jauh dari pusat, dimana seringkali rencana pemerintah tidak difahami oleh masyarakat setempat atau dihambat oleh elite lokal, dan dimana dukungan terhadap program pemerintah sangat terbatas.

5. Desentralisasi memungkinkan representasi yang lebih luas dari berbagai kelompok politik, etnis, keagamaan di dalam perencanaan pembangunan yang kemudian dapat memperluas kesamaan dalam mengalokasikan sumber daya dan investasi pemerintah.

6. Desentralisasi dapat meningkatkan kapasitas pemerintahan serta lembaga private di daerah, yang kemudian dapat meningkatkan kemampuan mereka untuk mengambil alih fungsi yang selama ini dijalankan oleh departemen yang ada di pusat. Dengan desentralisasi maka peluang bagi masyarakat didaerah untuk meningkatkan kapasitas teknis dan managerial.

7. Desentralisasi dapat meningkatkan efisiensi pemerintahan di pusat dengan tidak lagi pejabat puncak di pusat menjalankan tugas rutin karena hal itu dapat diserahkan kepada pejabat daerah. Dengan demikian pejabat pusat didaerah dapat menggunakan waktu dan energi mereka untuk melakukan supervisi dan pengawasan terhadap implementasi kebijaksanaan.

8. Desentralisasi juga dapat menyediakan struktur di mana berbagai departemen di pusat dapat dikoordinasi secara efektif bersama dengan pejabat daerah dan sejumah NGOs di berbagai daerah. Propinsi, kabupaten dan kota dapat menyediakan basis wilayah koordinasi bagi program pemerintah, khususnya di dunia ke III di mana banyak sekali program pedesaan yang dijalankan.

9. Struktur pemerintahan yang didesentralisasikan diperlukan guna melembagakan partisipasi masyarakat dalam perencanaan dan implementasi program. Struktur seperti itu dapat merupakan wahana bagi pertukaran informasi yang mmenyangkut kebutuhan masing-masing daerah kemudian secara bersama-sama menyampaikannya kepada pemerintah.

10. Dengan menyediakan modal alternatif cara pembuatan kebijaksanaan, desentralisasi dapat meningkatkan pengaruh atau pengawasan atas berbagai aktifitas yang dilakukan oleh elit lokal, yang seringkali tidak simpatik dengan program pembangunan nasional dan tidak sensitive terhadap kebutuhan kalangan miskin di pedesaan.

11. Desentralisasi dapat menghantarkan kepada administrasi pemerintahan yang mudah disesuaikan, inovatif, dan kreatif. Pemerintah daerah dapat memiliki peluang untuk menguji inovasi, serta bereksperimen dengan kebijaksanaan yang baru di daerah-daerah tertentu tanpa harus menjustifikasinya kepada seluruh wilayah negara. Kalau mereka berhasil maka dapat dicontoh oleh daerah yang lainnya.

12. Desentralisasi perencanaan dan fungsi manajemen dapat memungkinkan pemimpin di daerah menetapkan pelayanan dan fasilitas secara efektif di tengah-tengah masyarakat, mengintegrasikan daerah-daerah yang 


\section{MEDIA
HUKUM}

terisolasi, memonitor dan melakukan evaluasi implementasi proyek pembangunan dengan lebih baik dari pada yang dilakukan oleh pejabat di daerah.

13. Desentralisasi dapat memantapkan stabilitas politik dan kesatuan nasional dengan memberikan peluang kepada berbagai kelompok masyarakat di daerah untuk berpartisipasi secara langsung dalam pembuatan kebijaksanaan, sehingga dengan demikian akan meningkatkan kepentingan mereka di dalam memelihara sistem politik.

14. Desentralisasi dapat meningkatkan penyedia barang dan jasa di tingkat lokal dengan biaya yang lebih rendah, karena hal itu tidak lagi menjadi beban pemerintah pusat karena sudah diserahkan kepada daerah.

Penyelenggaraan pemerintahan di daerah adalah penyelenggaraan pemerintahan di pusat, sehingga apapun yang terjadi di daerah akan mempengaruhi jalannya pemerintahan di pusat begitu pula sebaliknya apapun yang terjadi di pusat akan berdampak di daerah. Oleh karena itu hubungan antara pemerintah pusat dan pemerintah daerah tidak akan terputus. Hubungan antara pemerintah pusat dan daerah bagaikan orang tua dan anaknya yang selalu akan terjalin meskipun kadang-kadang terjadi konflik dalam hubungan tersebut. Selama bentuk negara Indonesia masih berbentuk kesatuan, maka hubungan tersebut akan terus ada (Wijayanti dan Satriawan, 2009:158).

Otonomi daerah adalah subsistem dari sistem pemerintahan sebuah negara yang juga menjadi bagian dari sistem yang lebih luas. Kompleksitas sistem tersebut amat berpengaruh pada kesuksesan mengelolanya. Kompleksitas otonomi disumbang oleh segi-segi yang melingkupinya. Segi-segi tersebut, antara lain, pertama; segi hukum. Hukum otonomi adalah segi yang dipenuhi oleh warna kompleksitas yang besar. Kompleksitas hukum otonomi selain disumbang oleh hukum nasional juga oleh hukum lokal. Bahkan, hukum otonomi di beberapa tempat di Indonesia mengandung unsur hukum lokal yang berada di luar hukum negara, yakni hukum adat setempat. Kedua; politik. Kompleksitas politik yang mempengaruhi jalannya otonomi daerah lebih banyak didominasi oleh kompleksitas politik lokal. Namun, politik nasional sering kali jadi variabel antara politik nasional bahkan seolah jadi prasyarat membaiknya politik lokal. Artinya, politik lokal akan membaik jika politik nasional mampu diperbaiki. Oleh karena itu, wajar masyarakat Indonesia mendambakan Jokowi sebagai pemimpin nasional agar mampu mengatasi segala masalah lokal yang begitu beragam di Indonesia. Ketiga; birokrasi. Kompleksitas birokrasi justru sebaliknya: birokrasi nasional-lah yang lebih banyak berperan dalam kesuksesan mengelola kompleksitas otonomi daerah. Birokrasi nasional harus sepenuhnya mendukung otonomi daerah. Meski akhirnya manajemen pemerintahan di daerah dilaksanakan oleh birokrasi lokal, birokrasi nasional yang setengah hati dalam otonomi mampu membuat otonomi daerah gagal. Birokrasi nasional harus mampu memberikan teladan bagi cara kerja birokrasi lokal. Dalam hal ini sistem pembagian urusan jadi tumpuan. Dengan kata lain, kompleksitas birokrasi disumbang oleh sistem pembagian urusan. Pembagian urusan yang tidak clear-cut akan membawa kompleksitas birokrasi dalam kebijakan otonomi daerah, yang dapat bermasalah pada kemudian hari. Keempat; sosial-budaya. Kompleksitas sosialbudaya menyangkut keadaan masyarakat setempat dan sistem nilai yang berkembang. Soal ini pertama-tama akan dihadapi oleh struktur formal dalam pemerintahan daerah. Pertanyaannya, tidakkah Indonesia sangat beragam? Apakah hukum nasional mampu jadi tumpuan keberagaman itu? Keberagaman dan kreativitas lokal yang tidak mampu tertampung dengan baik dalam sistem hukum nasional kelak membawa keterbatasan jalannya otonomi daerah itu sendiri. Keempat, kompleksitas itu saling terkait. Kompleksitas itu berada dalam sistem negara Republik Indonesia. Kompleksitas otonomi daerah di Indonesia adalah produk dari kompleksitas negara dan bangsa Indonesia yang berbentuk republik dengan sistem negara kesatuan. Bentuk dan sistem pemerintahan negara Republik Indonesia adalah alat mencapai cita-cita bangsa Indonesia. Oleh karena itu, kompleksitas yang melingkupinya adalah kompleksitas dari alat pencapaian cita-cita bangsa, pemerintahan Jokowi-Kalla tidak mungkin efektif jika tak mampu memahami kompleksitas yang ada (Irfan, Kompas 11 Maret 2015).

Desentralisasi dan otonomi daerah yang berlangsung sejak 1 Januari 2001 adalah suatu peristiwa yang menimbulkan perubahan mendasar pada hubungan antara pemerintah pusat dan daerah, sekaligus mengubah perilaku sebagian 
masyarakat Indonesia yang sebelumnya hanya terfokus pada satu pusat kekuasaan, pemerintah pusat di Jakarta. Pentingnya desentralisasi dan otonomi daerah mungkin dapat disejajarkan dengan proses demokratisasi yang terjadi begitu drastis pada tahun 1998. Desentralisasi memang merupakan konsekuensi logis dari munculnya kehidupan demokrasi di Indonesia sejak berakhirnya rezim orde baru. Kedua proses tersebut bahkan mempunyai beberapa kesamaan yang tidak terbantahkan lagi. Kedua-duanya berlangsung pada saat perekonomian nasional sedang berada dalam kondisi sangat parah setelah krisis perekonomian 1998. Keduanya juga berlangsung dalam skala yang besar dan terjadi dalam masa yang sangat singkat, bahkan hampir tanpa masa transisi yang memadai (Huda, 2014:416).

Otonomi daerah di Indonesia memasuki babak baru dengan ditetapkannya Undang-Undang Nomor 23 Tahun 2014 tentang Pemerintahan Daerah. Perubahan pemerintahan daerah di Indonesia kalau mengacu dimensi waktu, sebenarnya relatif tidak panjang, apalagi kalau melihat perubahan pemerintahan daerah pasca reformasi, hanya kurang satu dasawarsa perubahan pengelolaan pemerintahan daerah mengalami berbagai perubahan. Perubahan kebijakan dalam hubungan pusat dan daerah tidak bisa dilepaskan dari konteks, format dan ideologi politik penguasa. Ketika penguasa baru saja tampil dan menyusun kekuatan, maka dikembangkan kebijakan yang agak terbuka. Namun ketika kekuasaan sudah berhasil mengkonsolidasi diri, maka kebijakan bisa dirubah dengan tertutup, otoritarisme atau malah totaliterisme. Munculah pergeseran dari ultra vires doctrine (merinci satu persatu urusan) menjadi open and arrangement a tau residual power (konsep kekuasaan sisa).

Konsep Desentralisasi dalam Undang-Undang Nomor 23 tahun 2014 ini adalah penyerahan Urusan Pemerintahan oleh Pemerintah Pusat kepada daerah otonomi. Sedangkan pengertian Otonomi Daerah adalah hak, wewenang, dan kewajiban daerah otonom untuk mengatur dan mengurus sendiri urusan pemerintahan dan kepentingan masyarakat setempat dalam sistem Negara Kesatuan Republik Indonesia. Hal ini sesuai dengan pasal 18 ayat (5) Undangt-Undang Dasar 1945 bahwa pemerintahan daerah menjalankan otonomi daerah seluas-luasnya, kecuali urusan pemerintahan yang oleh undang-undang ditentukan sebagai urusan pemerintah pusat.

Penyerahan urusan tersebut dimaksudkan membawa efisiensi dan efektivitas penyelenggaraan pemerintahan daerah yang perlu ditingkatkan dengan lebih memperhatikan aspek-aspek hubungan antara Pemerintah Pusat dengan daerah dan antar daerah, potensi dan keanekaragaman daerah, serta peluang dan tantangan persaingan global dalam kesatuan sistem penyelenggaraan pemerintahan negara. Selain itu penyelenggaraan pemerintahan daerah diarahkan untuk mempercepat terwujudnya kesejahteraan masyarakat melalui peningkatan pelayanan, pemberdayaan, dan peran serta masyarakat, serta peningkatan daya saing daerah dengan memperhatikan prinsip demokrasi, pemerataan, keadilan, dan kekhasan suatu daerah dalam sistem Negara Kesatuan Republik Indonesia.

Dalam Pasal 9 Undang-Undang Nomor 23 Tahun 2014 mengklasifikasi urusan Pemerintahan terdiri atas urusan pemerintahan absolut, urusan pemerintahan konkuren, dan urusan pemerintahan umum. Selanjutnya secara rinci disebutkan dalam pasal 10 ayat (1) mengenai urusan pemerintahan absolut yang merupakan sepenuhnya menjadi urusan pemerintah pusat meliputi: a. politik luar negeri; b. pertahanan; c. keamanan; d. yustisi; e. moneter dan fiskal nasional; dan f. agama. Sedangkan yang disebut sebagai urusan pemerintahan konkuren adalah Urusan Pemerintahan yang dibagi antara Pemerintah Pusat dan Daerah provinsi dan Daerah kabupaten/kota.Urusan pemerintahan konkuren yang diserahkan ke Daerah menjadi dasar pelaksanaan Otonomi Daerah. Urusan pemerintahan konkuren di dalam Pasal 9 ayat (3) dijelaskan bahwa yang menjadi kewenangan Daerah terdiri atas Urusan Pemerintahan Wajib dan Urusan Pemerintahan Pilihan. Urusan Pemerintahan Wajib terdiri atas Urusan Pemerintahan yang berkaitan dengan Pelayanan Dasar dan Urusan Pemerintahan yang tidak berkaitan dengan Pelayanan Dasar. Urusan Pemerintahan Wajib yang berkaitan dengan Pelayanan Dasar tersebut adalah Urusan Pemerintahan Wajib yang sebagian substansinya merupakan Pelayanan Dasar.

Selanjutnya dalam Pasal 12 ayat (1) dijelaskan bahwa Urusan Pemerintahan Wajib yang berkaitan dengan Pelayanan Dasar meliputi: a. pendidikan; b. kesehatan; c. pekerjaan umum dan penataan ruang; $d$. perumahan rakyat 


\section{MEDIA
HUKUM}

dan kawasan permukiman; e. ketenteraman, ketertiban umum, dan pelindungan masyarakat; dan f. sosial. Dalam pasal 12 ayat (2) Urusan Pemerintahan Wajib yang tidak berkaitan dengan Pelayanan Dasar sebagaimana dimaksud meliputi: a. tenaga kerja; b. pemberdayaan perempuan dan pelindungan anak; c. pangan; d. pertanahan; e. lingkungan hidup; f. administrasi kependudukan dan pencatatan sipil; g. pemberdayaan masyarakat dan Desa; h. pengendalian penduduk dan keluarga berencana; i. perhubungan; j. komunikasi dan informatika; k. koperasi, usaha kecil, dan menengah; I. penanaman modal; m. kepemudaan dan olah raga; n. statistik; o. persandian; p. kebudayaan; q. perpustakaan; dan r. kearsipan. Sedangkan Urusan Pemerintahan Pilihan diaturdalam Pasal 12 ayat (3) meliputi: a. kelautan dan perikanan; b. pariwisata; c. pertanian; d. kehutanan; e. energi dan sumber daya mineral; $f$. perdagangan; g. perindustrian; dan h. transmigrasi.

\section{Hubungan Antara Pusat dan Daerah}

\section{dalam otonomi Undang-Undang Nomor 23}

\section{Tahun 2014}

Desentralisasi adalah sebuah mekanisme penyelenggaraan pemerintahan yang menyangkut pola hubungan antara pemerintahan nasional dan pemerintahan lokal. Di dalam mekanisme ini pemerintahan nasional melimpahkan kewenangan kepada pemerintahan dan masyarakat setempat atau lokal untuk diselenggarakan guna meningkatkan kemaslahatan hidup masyarakat (Syaukani, dkk, 2009:xvii).

Hubungan antara Pemerintah Pusat (Pusat) dan Daerah mencakup isi yang sangat luas, bisa terkait dengan isu nasionalisme dan nation building, bisa pula dengan isu demokrasi nasional dan demokrasi lokal, dan oleh karena itu terkait pula dengan isu hubungan antara negara dan masyarakat. Hubungan antara Pusat dan Daerah merupakan sesuatu yang banyak diperbincangkan, karena masalah tersebut dalam praktiknya sering menimbulkan upaya tarik menarik kepentingan (spanning of interest) antara kedua satuan pemerintahan. Terlebih dalam negara kesatuan, upaya pemerintah pusat untuk selalu memegang kendali atas berbagai urusan pemerintahan sangat jelas (Huda, 2009:1).

Model Hubungan antara Pemerintah Pusat dan
Pemerintah Daerah secara teoritis menurut Clarke dan Steward dapat dibedakan menjadi tiga, yakni: (Huda, 2009:248) Pertama, The relative Autonomy Model, memberikan kebebasan yang relatif besar kepada pemerintah daerah dengan tetap menghormati eksistensi pemerintah pusat. Penekanannya adalah pada pemberian kebebasan bertindak bagi pemerintah daerah dalam kerangka kekuasaan/tugas dan tanggung jawab yang telah dirumuskan oleh peraturan perundang-undangan; kedua The Agency Model. Model dimana pemerintah daerah tidak mempunyai kekuasaan yang cukup berarti sehingga keberadaannya terlihat lebih sebagai agen pemerintah pusat yang bertugas untuk menjalankan kebijaksanaan pemerintah pusatnya. Karenanya pada model ini berbagai petunjuk rinci dalam peraturan perundangan sebagai mekanisme kontrol sangat menonjol. Pada model ini pendapatan asli daerah bukanlah hal penting dan sistem keuangan daerahnya didominasi oleh bantuan dari pemerintah pusat; ketiga The Interaction Model. Merupakan suatu bentuk model dimana keberadaan dan peran pemerintah daerah ditentukan oleh interaksi yang terjadi antara pemerintah pusat dan pemerintah daerah.

Menurut Bagir Manan, paling tidak ada empat faktor yang menentukan hubungan pusat dan derah dalam otonomi yaitu hubungan kewenangan, hubungan keuangan, hubungan pengawasan dan hubungan yang timbul dari susunan organisasi pemerintahan di daerah (Manan, 2001:37). Hubungan kewenangan antara lain bertalian dengan cara pembagian urusan rumah tangga daerah. Cara penentuan ini akan mencerminkan suatu bentuk otonomi terbatas atau otonomi luas. Dapat digolongkan sebagai otonomi terbatas apabila; pertama urusan-urusan rumah tangga daerah ditentukan secara kategoris dan pengembangannya diatur dengan cara-cara tertentu pula. Kedua; apabila sistem supervisi dan pengawasan dilakukan sedemikian rupa, sehingga daerah otonom kehilangan kemandirian untuk menentukan secara bebas cara-cara mengatur dan mengurus rumah tangga daerahnya. Ketiga; sistem hubungan keuangan antara pusat dan daerah yang menimbulkan hal-hal seperti keterbatasan kemampuan keuangan asli daerah yang akan membatasi ruang gerak otonomi daerah. Otonomi luas biasa bertolak dari prinsip semua urusan pemerintahan pada dasarnya menjadi urusan 
rumah tangga daerah, kecuali yang ditentukan sebagai urusan pusat.

Upaya menemukan format hubungan antara pusat dan daerah yang ideal dalam kerangka negara kesatuan bukanlah persoalan yang mudah ditemukan, karena hal itu merupakan proses yang berjalan seiring dengan perjalanan bangsa Indonesia. Salah satu aspek yang dapat mempengaruhi pola hubungan antara pemerintah pusat dan pemerintah daerah adalah susunan organisasi pemerintahan daerah, terlebih dalam negara kesatuan yang desentralistik. Kewenangan yang dijalankan oleh pemerintah pusat dalam negara kesatuan sangatlah luas dan mencakup seluruh warga negara yang ada di dalam maupun di luar negeri. Oleh karena itu, mutlak dilakukan delegasi kewenangan (delegation of authority) baik dalam rangka desentralisasi maupun dekonsentrasi. Sebagai konsekuensi dibentuknya satuan pemerintahan di tingkat daerah, sudah barang tentu disertai dengan tindakan lain yakni urusan-urusan pemerintahan apa saja yang dapat diserahkan dan dijalankan oleh satuan pemerintahan di daerah. Atau urusan-urusan pemerintahan yang akan diserahkan kepada pemerintah daerah sebagai konsekuensi pelaksanaan desentralisasi, titik berat pelaksanaan akan diletakkan pada daerah yang mana. Berdasarkan hal tersebut, maka susunan organisasi pemerintahan di daerah akan berpengaruh terhadap hubungan antara pusat dan daerah. Hal ini dapat dilihat dari peran dan fungsi masing-masing susunan atau tingkatan dalam penyelenggaaan otonomi. Artinya peran dan fungsi tersebut dapat ditentukan oleh pelaksanaan titik berat otonomi yang dijalankan. Pengaturan dan pelaksanaan titik berat otonomi sangat ditentukan oleh beberapa faktor yaitu: (a) sistem rumah tangga daerah; (b) ruang lingkup urusan pemerintahan; dan (c) sifat dan kualitas suatu urusan (Manan, 1995:194-195).

Berdasarkan ketentuan Undang-Undang Nomor 23 Tahun 2014 dapat diterjemahkan pola hubungan antara pemerintah pusat dan daerah sebagai berikut:

1. Desentralisasi adalah penyerahan sebagian kewenangan eksekutif dari Pemerintah Pusat kepada Daerah, dimana dalam pasal 9 (sudah disebutkan di halaman sebelumnya) bahwa Urusan pemerintahan Konkuren inilah yang menjadi dasar Otonomi Daerah. Urusan Pemerintahan
Konkuren yang diserahkan meliputi Urusan Wajib dan Urusan Pilihan. Pada Urusan Wajib ada Urusan Wajib Pelayanan dasar dan Urusan Wajib Non Pelayanan Dasar. Berdasarkan pembagian urusan kewenangan tersebut, merujuk pada teori Model Hubungan antara Pemerintah Pusat dan Pemerintah Daerah secara teoritis menurut Clarke dan Steward termasuk The Agency Model. Model dimana pemerintah daerah tidak mempunyai kekuasaan yang cukup berarti sehingga keberadaannya terlihat lebih sebagai agen pemerintah pusat yang bertugas untuk menjalankan kebijaksanaan pemerintah pusatnya. Karenanya pada model ini berbagai petunjuk rinci dalam peraturan perundangan sebagai mekanisme kontrol sangat menonjol.

2. Pembagian urusan pemerintahan konkuren tersebut berdasarkan Pasal 13 didasarkan pada prinsip akuntabilitas, efisiensi, dan eksternalitas, serta kepentingan strategis nasional. Prinsip akuntabilitas dimaksudkan bahwa Penanggungjawabnya berdasarkan kedekatannya dengan luas, besaran, dan jangkauan dampak yang ditimbulkan oleh penyelenggaraan suatu Urusan Pemerintahan. Adapun yang dimaksud dengan prinsip efisiensi adalah Perbandingan tingkat daya guna yang paling tinggi yang dapat diperoleh. Sedangkan Prinsip eksternalitas merupakan Luas, besaran, dan jangkauan dampak yang timbul akibat penyelenggaraan suatu Urusan Pemerintahan. Dan Prinsip kepentingan strategis nasional bahwa dalam rangka menjaga keutuhan dan kesatuan bangsa, kedaulatan Negara, implementasi hubungan luar negeri, pencapaian program strategis nasional dan pertimbangan lain.

3. Berdasarkan pasal 13 ayat (2) kriteria Urusan Pemerintahan yang menjadi kewenangan Pemerintah Pusat adalah:

a. Urusan Pemerintahan yang lokasinya lintas Daerah provinsi atau lintas negara;

b. Urusan Pemerintahan yang penggunanya lintas Daerah provinsi atau lintas negara;

c. Urusan Pemerintahan yang manfaat atau dampak negatifnya lintas Daerah provinsi atau lintas negara;

d. Urusan Pemerintahan yang penggunaan sumber dayanya lebih efisien apabila dilakukan oleh 
Pemerintah Pusat; dan/atau

e. Urusan Pemerintahan yang peranannya strategis bagi kepentingan nasional

4. Sedangkan yang menjadi kewenangan pemerintah daerah provinsi disebutkan dalam Pasal 13 ayat (3) meliputi;

a. Urusan Pemerintahan yang lokasinya lintas Daerah kabupaten/kota;

b. Urusan Pemerintahan yang penggunanya lintas Daerah kabupaten/kota;

c. Urusan Pemerintahan yang manfaat atau dampak negatifnya lintas Daerah kabupaten/kota; dan/atau

d. Urusan Pemerintahan yang penggunaan sumber dayanya lebih efisien apabila dilakukan oleh Daerah Provinsi;

5. Selanjutnya dalam Pasal 13 ayat (4) kriteria Urusan Pemerintahan yang menjadi kewenangan Daerah kabupaten/kota adalah:

a. Urusan Pemerintahan yang lokasinya dalam Daerah kabupaten/kota;

b. Urusan Pemerintahan yang penggunanya dalam Daerah kabupaten/kota;

c. Urusan Pemerintahan yang manfaat atau dampak negatifnya hanya dalam Daerah kabupaten/kota; dan/ atau;

d. Urusan Pemerintahan yang penggunaan sumber dayanya lebih efisien apabila dilakukan oleh Daerah kabupaten/kota.

6. Pembagian urusan kewenangan tersebut dikontrol oleh pemerintah pusat dengan menerapkan norma, standar, prosedur, dan kriteria (NPSK) dalam rangka penyelenggaraan Urusan Pemerintahan; dan melaksanakan pembinaan dan pengawasan terhadap penyelenggaraan Urusan Pemerintahan yang menjadi kewenangan Daerah. Hal ini tercantum dalam Pasal 16. Norma, standar, prosedur, dan kriteria tersebut berupa ketentuan peraturan perundang-undangan yang ditetapkan oleh Pemerintah Pusat sebagai pedoman dalam penyelenggaraan urusan pemerintahan konkuren yang menjadi kewenangan Pemerintah Pusat dan yang menjadi kewenangan Daerah. Penetapan norma, standar, prosedur, dan kriteria dilakukan paling lama 2 (dua) tahun terhitung sejak peraturan pemerintah mengenai pelaksanaan urusan pemerintahan konkruen diundangkan. Apabila dalam jangka waktu 2 (dua) tahun Pemerintah Pusat belum menetapkan norma, standar, prosedur, dan kriteria, penyelenggara Pemerintahan Daerah melaksanakan Urusan Pemerintahan yang menjadi kewenangan Daerah.

7. Pada pasal 18 ditentukan adanya skala prioritas pelaksanaan urusan, bahwa Pemerintahan Daerah memprioritaskan pelaksanaan Urusan Pemerintahan Wajib yang berkaitan dengan Pelayanan Dasar. Juga ditekankan bahwa Pelaksanaan Pelayanan Dasar pada Urusan Pemerintahan Wajib yang berkaitan dengan Pelayanan Dasar berpedoman pada standar pelayanan minimal (SPM) yang ditetapkan oleh Pemerintah Pusat. Dengan kata lain, Pemerintah provinsi dan Pemerintah kabupaten/Kota wajib memprioritaskan 6 (enam) urusan Pelayanan Dasar yang disebut pada Pasal 12, yaitu: pendidikan; kesehatan; pekerjaan umum dan penataan ruang; perumahan rakyat dan kawasan permukiman; ketenteraman, ketertiban umum, dan perlindungan masyarakat; dan sosial. Artinya keenam program pelayanan dasar ini mendapatkan prioritas pembiayaan, sumber daya manusia, Sarana/prasarana, dan manajemennya sehingga bisa berjalan baik ditingkat Provinsi dan Kabupaten/ Kota. Berkaitan dengan urusan wajib pemerintahan berkaitan dengan pelayanan dasar (8 urusan) tidak perlu diatur lagi di Daerah karena sudah memiliki SPM dan NSPKnya, sehingga Daerah sudah langsung dapat melaksanakannya;

8. Sedangkan berkaitan dengan urusan wajib non pelayanan dasar (18 urusan) perlu dilakukan pemetaan urusan masing-masing Daerah (Pasal 24), dimana bahwa intensitas masing-masing urusan tersebut pasti berbeda, hal ini dilakukan untuk menentukan tipologi SKPD. Semakin tinggi tipologi urusannya, maka alokasi APBN akan semakin besar, tidak selama ini yang dibuat sama rata di semua daerah. Pemetaan dilakukan dengan variable umum, terdiri dari jumlah penduduk, besaran APBD, dan luas wilayah, sedangkan untuk variable khususnya dapat disusun bersama-sama dengan kementerian/ lembaga terkait.

9. Menurut DR. Kurniasih, SH, M.Si selaku Direktur Urusan 
Pemerintah Daerah Wilayah I Ditjen Otonomi Daerah Kementerian Dalam Negeri. Sesuai dengan UU Nomor 23 Tahun 2014, terjadi peralihan kewenangan urusan pemerintahan, hal ini perlu segera dilakukan peralihan kewenangan tersebut, bukan dengan MoU (kesepakatan/ kerjasama) karena Pemerintah Daerah merupakan sub ordinat dari Pemerintahan diatasnya (http:// wirapati.raddien.com/2015/03/sosialisasi-implementasiuu-232014-bagi.html diakses pada 5 mei 2015). Perlu adanya penegasan terhadap kekuasaan pemerintahan, bahwa sesuai dengan Pasal 5 Undang-Undang Nomor 23 Tahun 2014, Presiden RI memegang kekuasaan pemerintahan sesuai dengan Undang-Undang Dasar 1945 dimana kekuasaan pemerintahan tersebut diurai ke dalam berbagai urusan pemerintahan, dimana berbagai urusan pemerintahan tersebut dilaksanakan di Daerah berdasarkan asas Desentralisasi, Dekonsentrasi, dan Tugas Pembantuan. Selanjutnya beliau menjelaskan bahwa untuk pemetaan urusan pilihan berdasarkan potensi, proyeksi penyerapan tenaga kerja, dan pemanfaatan lahan, dimana tujuan dari pemetaan ini adalah menentukan Daerah apakah mempunyai atau melaksanakan urusan pemerintahan pilihan dimana Pemetaan urusan pemerintahan ini secara umum bertujuan untuk menyusun SOTK Pemerintah Daerah dimana nomenklatur perangkat daerah harus memperhatikan pedoman dari kementerian/lembaga pemerintah non kementerian terkait. Hal ini diatur dalam Pasal 211.

10. Undang-Undang Nomor 23 Tahun 2014 ini pun berpedoman dengan Undang-Undang Nomor 5 tahun 2014 tentang Aparatur Sipil Negara, dimana tujuan umumnya antara lain: (a) Untuk menjaga profesionalisme dan menjauhkan birokrasi dari intervensi politik maka perlu diatur Standar Kompetensi Jabatan dalam birokrasi pemerintah daerah dan (b) Selain memenuhi kompetensi teknis, kompetensi manajerial dan kompetensi social cultural menjadi pertimbangannya.

11. Berkaitan dengan Surat Edaran Menteri Dalam Negeri Nomor 120/253/SJ tanggal 16 Januari 2015 perlu ditekankan kembali bahwa: (a) Dengan berlakunya Undang-Undang 23 Tahun 2014 otomatis urusan pemerintahan harus beralih, sedangkan yang diberikan tenggang waktu diselesaikan 2 tahun ke depan adalah yang berkaitan dengan Personel, pendanaan, Sarana dan prasarana serta dokumen (P3D). Hal ini sesuai dengan Pasal 404 Undang-Undang Nomor 23 Tahun 2014 dan (b) Perubahan SOTK dilakukan setelah adanya pemetaan urusan pemerintahan, Provinsi perlu melakukan pemetaan urusan Kabupaten/Kota didampingi oleh Kementerian/ Lembaga Pemerintah Non kementerian. Yang perlu diperhatikan adalah akibat adanya peralihan kewenangan, seperti personil/pegawai, aset dan pendanaannya.

Apabila dicermati, Pada Undang-Undang Nomor 23 Tahun 2014, masih menerapkan pola residual power atau open arrangement, bahkan urusan pemerintah dibagi menjadi urusan pemerintah absolut, urusan pemerintah konkruen dan urusan pemerintahan umum (pasal 9) urusan pemerintah absolut adalah urusan pemerintah yang sepenuhnya menjadi kewenangan pemerintah pusat (politik luar negeri, pertahanan, keamanan, yustisi, moneter dan fiskal, dan agama) urusan pemerintah konkruen adalah Urusan Pemerintahan yang dibagi antara Pemerintah Pusat dan Daerah provinsi dan Daerah kabupaten/kota. Urusan pemerintahan umum adalah Urusan Pemerintahan yang menjadi kewenangan Presiden sebagai kepala pemerintahan. Selain itu dalam Undang-Undang Nomor 23 Tahun 2014, Dewan Perwakilan Rakyat Daerah masih sama kedudukannya dengan Undang-Undang Nomor 23 Tahun 2004 yakni sebagai bagian dari penyelenggara pemerintahan daerah (http://harryuban.blogspot.com/2014/12/review UU No 23 diakses pada15 Mei 2015).

Adanya pembagian urusan antara pemerintah pusat dan daerah tersebut mencerminkan bahwa Indonesia masih menjalankan adanya bentuk negara kesatuan. Daerah diberi kewenangan namun sudah diperinci dalam undangundangnya, hal ini memberikan penafsiran bahwa pemberian kewenangan tersebut masih di bawah kontrol dan kendali dari pemerintah pusat. Apabila dikaitkan dengan teori Clarke dan Steward, model hubungan antara pemerintah pusat dan daerah bisa dikategorikan menganut The Agency Model. Model dimana pemerintah daerah tidak mempunyai kekuasaan yang cukup berarti sehingga keberadaannya terlihat lebih sebagai agen pemerintah pusat yang bertugas 


\section{MEDIA
HUKUM}

untuk menjalankan kebijaksanaan pemerintah pusatnya. Karenanya pada model ini berbagai petunjuk rinci dalam peraturan perundangan sebagai mekanisme kontrol sangat menonjol.

Hal ini sangat wajar mengingat proses pemberian kewenangan dari pemerintah pusat ke daerah dilatarbelakangi oleh beberapa faktor dan sistem politik yang terjadi di Indonesia. Pemerintah pusat tidak menginginkan adanya kebebasan pemerintah daerah dalam menjalankan kewenangan yang diberikan dalam undang-undang, namun masih ada pengawasan dan kontrol yang harus dilakukan pemerintah pusat.

\section{PENUTUP}

Berdasarkan pemaparan di atas, dapat disimpulkan bahwa ketentuan Undang-Undang Nomor 23 Tahun 2014 tentang pemerintahan daerah masih mengarah pada desentralisasi, dilihat dari adanya pembagian urusan meskipun diklasifikasikan secara rinci ke dalam 3 urusan pemerintahan. Jika merujuk pada teori model hubungan antara Pemerintah Pusat dan Pemerintah Daerah secara teoritis menurut Clarke dan Steward, desentralisasi seperti ini termasuk The Agency Model. Model dimana pemerintah daerah tidak mempunyai kekuasaan yang cukup berarti sehingga keberadaannya terlihat lebih sebagai agen pemerintah pusat yang bertugas untuk menjalankan kebijaksanaan pemerintah pusat. Karenanya pada model ini berbagai petunjuk rinci dalam peraturan perundangan sebagai mekanisme kontrol sangat menonjol. Ini merupakan konsekuensi bentuk negara kesatuan, dimana pemerintah pusat yang mengendalikan penyelenggaraan pemerintahan. Bentuk kontrol pemerintah pusat diwujudkan dengan adanya penyerahan urusan tersebut melalui penyusunan norma, standar, prosedur dan kriteria (NPSK) yang disusun oleh pemerintah pusat sebagai landasan bagi pemerintah daerah melaksanakan urusan yang telah diberikan oleh pemerintah pusat. Selain itu pemerintah pusat juga dilakukan pembinaan dan pengawasan terhadap penyelenggaraan Urusan Pemerintahan yang menjadi kewenangan Daerah. uusan pemerintahan antara kementerian dengan pemerintahan daerah, Presiden melimpahkan kewenangan kepada Menteri Dalam Negeri untuk bertindak selaku kordinat

\section{DAFTAR PUSTAKA}

\section{Buku-buku}

Bagir Manan, Menyongsong Fajar Otonomi Daerah, Yogyakarta, PSH FH UII, 2001

-, Hubungan Pusat dan Daerah Menurut UUD 1945, Pustaka Sinar Harapan, Jakarta, 1995.

Krishna d. Darumurti, Umbu Rauta, Otonomi Daerah; Perkembangan pemikiran, pengaturan dan pelaksanaan, Citra Aditya Bakti Bandung, 2003

MPR RI, Panduan dalam Memasyarakatkan UUD Negara Republik Indonesia tahun 1945, Sekretariat Jenderal MPR RI, Jakarta, 2003

M.Laica Marzuki, Berjalan-jalan di Ranah Hukum, Buku Kesatu, Edisi Revisi Cetakan kedua, Sekretariat Jenderal \& Kepaniteraan Mahkkamah Konstitusi RI, Jakarta, 2006,

M.Solly Lubis, Pergeseran Garis Politik dan Perundangundangan Mengenai Pemerintah Daerah,Bandung, Alumni, 1983,

Ni'matul Huda, Perkembangan Hukum Tata Negara Perdebatan dan Gagasan Penyempurnaan, Yogyakarta, FH UII Press, 2014.

_-_-__-_-_, Hukum Pemerintahan Daerah, Bandung, Nusa Media, 2009.

Sadu Wasistiono, Kajian Hubungan antara Pemerintah Pusat dengan Pemerintah Daerah (Tinjauan dari sudut pandang manajemen Pemerintahan), Jurnal Administrasi Pemerintahan Daerah, volume I, Edisi kedua 2004

Septi Nur Wijayanti, Iwan Satriawan, Hukum Tata Negara Teori dan Prakteknya di Indonesia, Fakultas Hukum UMY bekerja sama dengan Divisi Publikasi dan Penerbitan LP3M UMY, Yogyakarta, 2009.

Syaukani, HR, Afan Gaffar, Ryaas, Rasyid, Otonomi Daerah Dalam Negara Kesatuan, Cetakan VII, Pustaka Pelajar Offset, Jakarta, 2009

\section{Peraturan Perundang-undangan}

UUD 1945

UU Nomor 32 Tahun 2004 tentang Pemerintahan Daerah

UU Nomor 23 Tahun 2014 tentang Pemerintahan Daerah

Surat Edaran Menteri Dalam Negeri Nomor 120/253/ 
Sj tentang Penyelenggaraan urusan Pemerintahan Setelah Undang-Undang Nomor 23 Tahun 2014 tentang Pemerintahan Daerah

\section{Internet dan Media}

Irfan Ridwan maksum, Kompleksitas Otonomi, Kompas, 11 Maret 2015

Suprijanto Rijadi, enam Perda Urusan Wajib Pemerintah Daerah, http://birokrasi. kompasiana. com/2014/12/24/enam-perda-urusan-wajibpemerintah-daerah-698638.html, diakses pada tanggal 6 Mei 2015

http://wirapati.raddien.com/2015/03/sosialisasiimplementasi-uu-232014-bagi.html, diakses pada tanggal 5 mei 2015

http://harryuban.blogspot.com/2014/12/review UU No 23 Tahun 2014 tentang.html., diakses pada tanggal 15 Mei 2015 